5. Рубинштейн С. Л. Основы общей психологии. / С. Л. Рубинштейн - СПб.: Питер, 2005.

6. Чабанный В.Ф. управление самодеятельным хором [ Текст]/ В.Ф. Чабанный. - Москва: 2009.

7. Черкасов В. Ф. Теорія і методика музичної освіти : навч. посібник. Тернопіль : Навчальна книга «Богдан», 2014. 472 с.

DOI https://doi.org/10.30525/978-9934-26-041-4-12

\title{
ГОТОВНІСТЬ СТУДЕНТІВ СПЕЦІАЛЬНОСТІ «ПОЧАТКОВА ОСВІТА» ДО ВИХОВАННЯ ТОЛЕРАНТНОСТІ У МОЛОДШИХ ШКОЛЯРІВ
}

\author{
Коваль Т. В. \\ кандидат педагогічних наук, \\ доцент кафедри педагогіки та методики початкового навчання \\ Національний педагогічний університет імені М. П. Драгоманова \\ м. Київ, Україна
}

Готовність майбутнього вчителя початкових класів до виховання толерантності у молодших школярів $€$ компонентом готовності до педагогічної діяльності. Це складне соціально-педагогічне утворення, яке містить у собі комплекс цінностей, якостей толерантного спрямування, професійно-педагогічних знань загального характеру, які входять до змісту соціально-гуманітарних і професійно-орієнтованих дисциплін і спеціальних про основи толерантності, технологій здійснення виховання толерантності, спрямованістю професійнопедагогічних умінь і навичок щодо їх використання в практичній роботі з молодшими школярами [4, с. 342].

Готовність майбутнього вчителя до виховання толерантності у молодших школярів виділяємо як частину професійної компетентності вчителя початкових класів і певний стан, який виникає внаслідок інтеграції мотивів, установок, цінностей, індивідуально-психологічних якостей, професійно-педагогічних знань, умінь і навичок, досвіду 3 виховання толерантності у молодших школярів. Цілісність цього утворення визначається повноцінним розвитком його складових компонентів. 
Враховуючи той факт, що готовність виникає внаслідок досвіду людини, який грунтується на формуванні позитивного ставлення до діяльності, усвідомленні мотивів та потреб у неї, способів взаємодії $з$ ним, важливим $є$ позитивне ставлення до виховної діяльності толерантного спрямування, емоційні, вольові та інтелектуальні характеристики поведінки особистості. Готовність до виховання толерантності включає когнітивну, емоційно-мотиваційну та поведінкову складові. Таким чином, у загальному вигляді готовність до виховання толерантності структурно передбачає:

- гуманістичне позитивне толерантне ставлення до дитини і різних видів діяльності, що пов'язані 3 іiі розвитком та вихованням толерантності;

- здібності та особистісні якості, що відповідають вимогам технології толерантності;

- знання, вміння та навички;

- потреби та інтерес;

- практична діяльність із виховання толерантності у молодших школярів.

Мотиваційний етап передбачає «занурення» майбутніх учителів в емоційно забарвлене, інтенсивне, значуще та привабливе для них проблемно-освітне середовище, яке дозволяє продемонструвати важливість толерантності для сучасного світу та людини. В результаті формуються уявлення та знання про різноманіття культур у світі, толерантність; про себе, як представника полікультурного суспільства; установок на виховання толерантності та толерантну поведінку. Як наслідок, активізуються інтелектуальна, мотиваційна та емоційна сфери особистості [3, с. 43].

Мета мотиваційного етапу:

- сформувати уявлення та знання про цінність толерантності, мету та завдання виховання толерантності;

- сформувати свідоме ставлення до виховання толерантності в учнів початкової школи;

- сформувати професійні та суспільні мотиви виховання толерантності в учнів;

- стимулювати бажання використовувати отриманні знання та вміння на практиці;

- сформувати спрямованість на толерантну взаємодію із суб'єктами навколишнього середовища.

На змістовому i процесуальному етапах закладається основа теоретичних знань і методичних умінь 3 виховання толерантності, а 
також формується міжкультурна педагогічна компетентність та компетентність 3 виховання толерантності в учнів [2, с. 234].

Мета змістового та процесуального етапів:

- сформувати уявлення та знання про культуру, різні шляхи іiі прояву та усвідомити важливість дослідження власного культурного походження;

- сформувати уявлення та знання про себе як представника соціуму, етносу, культури та вміння здійснювати самопізнання;

- сформувати уявлення та знання про полікультурний простір життєдіяльності, психологічні особливості представників різних культур;

- сформувати знання про прояви толерантності та інтолерантності в учнівському колективі;

- способи побудови толерантної взаємодії в умовах полікультурного освітнього простору;

- сформувати вміння із самовиховання толерантності та організації толерантної взаємодії;

- забезпечити знаннями про прояви толерантності та інтолерантності в класі та способах створення толерантного освітнього середовища;

- сформувати вміння зі створення толерантного освітнього середовища, а також планування, здійснення та аналізу виховання толерантності;

- забезпечити оволодіння майбутніми вчителями навчальними методиками та технологіями, які сприяють розумінню культури та іiі ролі у житті окремої людини і суспільства в цілому;

- оволодіти інтерактивними технологіями виховання толерантності в учнів;

- ознайомити з труднощами та проблемами організації виховання толерантності в учнів.

Характеристиками готовності майбутнього вчителя до виховання толерантності є:

- усвідомлення актуальності i значимості ідей i цінностей виховання толерантності;

- обгрунтування своїх дій, самореалізація на основі внутрішньої професійної мотивації;

- постійний пошук альтернатив існуючий практиці виховання;

- спільне з учнями осмислення елементів виховання;

- рефлексія власної та професійної поведінки;

- відповідальність за прийняті рішення; 
- орієнтація на діалог та комунікацію в процесі педагогічного спілкування тощо [1].

Готовність до педагогічної діяльності передбачає формування толерантності, яка забезпечать майбутньому педагогу можливість усвідомлено і компетентно здійснювати професійну діяльність щодо виховання молодших школярів.

\title{
Література:
}

1. Байбаков А.М. Модель развития толерантности старшего подростка как ориентир в педагогическом целеполагании. - Интернет. http.: // www.rambler.ru.

2. Бондарева С. К., Колесов Д.В. Толерантность. Введение в проблему.: М. - Воронеж, 2003. - 273 с.

3. Проблемы формирования толерантного сознания в воспитательной работе с учащимися // Тезисы научно-практической конференции. Институт повышения квалификации Кургансокй области. - Курган: ИП-КиПРО, 2003. - 58 с.

4. Психология. Словарь. / Под общ. ред. А.В. Петровского, М.Г. Ярошевского. - 2-е изд. - М. : Политиздат, 1990. - 494 с.

\section{DOI https://doi.org/10.30525/978-9934-26-041-4-13}

\section{КОНФЛІКТОЛОГІЧНА КОМПЕТЕНТНІСТЬ ТА МЕДИАТИВНА ДІЯЛЬНІСТЬ ПЕДАГОГА ПРИ ВИРІШЕННІ КОНФЛІКТІВ У ЗАКЛАДІ ВИЩОЇ ОСВІТИ}

\author{
Козич I. В. \\ кандидат педагогічних наук, \\ доцент кафедри педагогіки та психології освітньої діяльності \\ Запорізький наиіональний університет \\ м. Запоріжжя, Україна
}

Конфлікти у закладі вищої освіти, як і в суспільстві загалом, $є$ постійним явищем, проте діяльність педагога передбачає створення та підтримку позитивного мікроклімату в освітньому середовищі. Навчальне середовище - складне явище, яке включає різні рівні взаємодії всіх учасників навчально-виховного процесу. Актуальність питання 